\title{
For a Better Tomorrow
}

\author{
Para un Futuro Mejor
}

\section{Para um futuro melhor}

\author{
Madeléne Beckman * \\ The Swedish Centre for Architecture and Design
}

\begin{abstract}
This article presents how the Swedish Centre for Architecture and Design (ArkDes) in Stockholm, Sweden work with architectural education to reach social justice as a part of its instruction. It describes some of ArkDes pedagogical ideas as well as presenting practical examples from the work at ArkDes. It also presents international architectural education-work done in Ukraine, Belarus, Moldova and Georgia in collaboration with dance and movement. It stresses the importance of architectural education as a tool to understand your surroundings and ways and methods to enhance knowledge of architecture with the purpose that you tomorrow can make better decisions for the society so that we can create a more equal world. The article shows how architecture education can strengthen learning and improve self-esteem.
\end{abstract}

Keywords: Art education, Rights of the children, Self-esteem, Communication skills, Sweden.

Este artículo presenta cómo el Centro Sueco de Arquitectura y Diseño (ArkDes) en Estocolmo (Suecia) trabaja la educación arquitectónica para llegar a la justicia social como parte de su enseñanza. Se describen algunas de las ideas pedagógicas de ArkDes, así como ejemplos prácticos de la obra de ArkDes. También se presenta la educación arquitectónica desde una perspectiva internacional, trabajo realizado en Ucrania, Bielorrusia, Moldavia y Georgia que incluye danza y movimiento. Se hace hincapié en la importancia de la educación arquitectónica como una herramienta para entender su entorno, formas y métodos para mejorar el conocimiento de la arquitectura con el fin de que se tomen mejores decisiones para la sociedad y crear un mundo más igual. El artículo muestra cómo la educación arquitectónica puede fortalecer el aprendizaje y mejorar la autoestima.

Descriptores: Educación artística, Derechos de los niños, Autoestima, Habilidades de comunicación, Suecia.

Este artigo apresenta o trabalho de educação em arquitectura do Centro Sueco de Arquitetura e Design (ArkDes), em Estocolmo, Suécia, cujo principal objetivo é alcançar a justiça social. São descritas algumas das ideias pedagógicas do ArkDes através de alguns exemplos práticos, além das experiências de educação em arquitectura na Ucrânia, Belarus, Moldávia e Geórgia, onde também foram utilizadas a dança e o movimento corporal. É salientada a importância da educação em arquitectura como uma ferramenta para a compreensão do contexto e como forma para melhorar o conhecimento da disciplina com o propósito de permitir uma melhor tomada de decisão para uma sociedade mais igualitária. O artigo mostra como a educação em arquitetura pode fortalecer a aprendizagem e melhorar a autoestima.

Palavras-chave: Educação artística, Direitos das crianças, Autoestima, Habilidades de comunicação, Suécia.

*Contacto: madelene.beckman@arkdes.se

ISSN: 2254-3139

www.rinace.net/riejs/

revistas.uam.es/riejs
Recibido: $\quad 3$ de diciembre 2016

$1^{\text {a }}$ Evaluación: 30 de enero 2017

Aceptado: $\quad 26$ de febrero 2017 


\section{Introduction}

To give children a voice based on knowledge is one of the main aims for The Swedish Centre for Architecture and Design, called ArkDes. This has taken us round the world as well as acting within the borders of Sweden. In this article, I'm going to give some examples of how we work and describe some of the projects that I have done the last couple of years within the field of architecture education.

ArkDes is situated in the center of Stockholm, on an island that used to be a naval base. It makes it feel a bit secluded and with a touch of being in the archipelago and yet it is in the middle of the capital. The architecture on the island origins mostly from the classicistic era when the navy was located on the island, architecture that plays with the idea of rhythm, order and plastered surfaces as its characteristics. In the old drill hall ArkDes is situated since 1998.

ArkDes was founded as The Swedish Museum of Architecture 1978 by the Swedish state and our collections comes from Architects Sweden that already during the 1950'ies started an archive of photos and later also drawings. For twenty years, the museum was a rather small organization, mostly known amongst people interested in architecture but things were to be changed. In the beginning of the 1990'ies the museum was looking for other than the Hydrographic Office it was situated in at the time.

Close by, the Museum of Modern Art, Moderna Museet, on the other hand was situated in the old naval drill halls. Higher demands on controlled climate and safety made the halls unsuited for art exhibitions but the could suite for exhibitions of architecture. The existing buildings were too small to host a modern museum organization and the Moderna Museet also needed new localities. An architecture competition was announced for both a new museum for modern art as well as a building for the museum of architecture. The competition was won by the Spanish/Catalan architect Rafael Moneo. The stipulation to get access to the new buildings for the Swedish Museum of Architecture was that museum was to develop pedagogical programs for children and youth.

1998 the museum moved into the new building as well as the renovated old drill halls. In the end of the hall with the permanent exhibition a high glass walls with gigantic sliding glass doors the workshop was situated. The idea is to not to hide the activities for the children in some basement or some other far away area but to put them in the center of the museum where all the visitors can see the activities. The design is thought to lower the threshold for taking part in the activities for both families, adults as well as for schools.

ArkDes is a national authority and therefore an important part of the democratic system in Sweden. A democracy that believes and work for social justice and equal opportunities for all citizens, no mater background, age, sex or religion. We all live together in a man made environment, in cities, villages and communities. We all use roads, buildings and places that are man made. I find it therefore utterly important that we also learn and understand how those environments were created, what sort of systems that creates them, why buildings and spaces looks the way they do. What does their history tell us about the past and by knowing the past, how do we want to create the future, to work towards the future with equal rights, social justice and freedom of speech for everyone. So we work much with history as well as how spaces are created. When we talk about 
architecture we have a very broad definition of it from décor to how to create a sustainable society.

\section{Methods}

The way we work is based on the idea of that we all learn in different ways. We then have to be able to meet all this way and that is no matter the age of the participants. We also belief in the idea of "learning by doing" and that all the participants are experts on their own environment and therefore specialists in their surroundings.

I think that this is an important statement, that we all are specialist in our own environment. That gives us a meeting between persons that are specialists, not a meeting between someone that knows and someone that doesn't. Then of course we know different things and are specialist in our own fields but yet we both carry our own knowledge and can meet with respect of each other's knowledge. What we are trying to do with our knowledge is to give them a vocabulary, let them put words on their knowledge and enhance the level of knowledge by adding layers of stories to widen their perception of space. What we get is a more vivid picture of society.

I am now going to give you some examples from each field that we work in and in that way try to exemplify how we work to support and improve social justice. Hopefully inspire you how you can work in the environment that you interact in.

\section{School programmes}

The exhibitions are one of the corner stones of the education at ArkDes. We mostly work in our permanent exhibition Architecture in Sweden -a thousand years of architecture- function, design and aesthetic. It is a fantastic exhibition with many different layers which gives us the opportunity to tell multiple stories. As a complement to the story we start with an experience of the only architecture that we have access to, our building.

\section{The dilemma to work through representations}

Art museums show real art, science museums can show real machines but we can't show the real architecture, with one exception: our own buildings. That makes us a bit unique in the museum family. We are therefore very lucky to have beautiful buildings, both old and contemporary. Buildings of a high quality and well designed. We start our school programs with an exercise when we "walk in the ceiling". You can really see how many different thoughts are running through in their minds. The younger children from the age of four immediately starts to think of solutions like glue or suction cups, the older mostly look at me as if I was crazy and say that it is impossible and why should they do that? I often ask them to pose that question after we have done the exercise and they accept that. Doing the walk, I hear a lot of laughter and ohhh's. So why then? Many reasons. They have been travelling to get to the museum so their attention is a bit everywhere and this is a fantastic way to collect the group and get their attention. You really get an idea of the notion of space, the high celling gets deep and you have to step over things that you normally don't have to. The most important, it is great fun. A better feeling than joy, before you get into a learning situation, doesn't exist. So what do we do then? We use mirrors made out of acrylic that we leaning on our noses. When 
looking into the mirror we see the ceiling. An exercise that in its simplicity really does the work.

Architecture, unlike other art forms have a very basic side, it gives us shelter and protects us if it is a sound construction and well built. Therefore, that part of architecture is great to study within the subject of technology in schools. All our programs for schools is linked to the school curriculum. In Sweden the schools are a question for the municipalities but the government decides the curriculum. As a national authority we don't have to (or maybe shouldn't) follow the curricula but at the same time we want to be of importance for the schools. Schools today have a strict schedule and little money so we need to be an attractive place, a place where they can fulfil their goals. So we connect our activities to the curricula but we can give something else as well.

When thinking of your days back in school, do you remember visits outside school best or a normal weekday? My guru is Anne Bamford and her book The Wow Factor from 2006. And to make a long story short she shows that art education improves learning in all subjects including mathematics and language. Just imagine what the result would be if you used art-rich education processes in those subjects as well. She also finds and here I quote: "Arts education increases co-operation, respect, responsibility, tolerance, and appreciation, and has a positive impact on the development of social and cultural understanding" (Bamford, 2009, p. 144)

\section{The importance of dialogue}

The next part of our school program takes place in the exhibition. We have three main tracks through the permanent exhibition Architecture in Sweden. 1. Technology, material and construction; 2. The history of Architecture; 3. City development. The classes can come back five times and then we add Antiquity and the architecture in the Middle Ages and how those periods have influenced architecture in Sweden. More recently Sustainable city development has become more popular, it's a mirror of what happens in our society today. Here we work with the three legs of sustainability; economical, social and ecological.

When working in the exhibition I find it important to find a dialogue with the participants, to find their level of knowledge and have that as a base for the tour. There is no point of talking over people's heads assuming that they know what you are talking about, you have to find common grounds. We work a lot by posing questions. Sometimes open questions that everyone can answer in chorus or asking them to raise their hands and answer individually. One method is asking them to discuss the question in groups of two or three. In that way you activate all participants and the ones that don't like to speak up in public also have a chance to talk. It is also easier to say that "we think" instead of "I think".

Discussions and questions are parts of the method. We also try to implement exercises that the participants can do as a part of the guided tour. Two examples from the track of technology are about steel. We talk about the difference of cast and rolled iron. I give the participants a piece of paper and ask them (preferably in smaller groups) to make the paper able to carry weight. It is a perfect way to talk about and show that just by changing the shape of the paper by rolling or fold (bending) you can make the paper take weight. Then you can connect the exercise to the real material, steel and talk about 
beams and then to the building that you are look at. The next exercise shows how we work to get our participants to understand framework. In these two examples we often talk about an elevator in Stockholm or roller coaster's, children seem to know a lot about the last.

The aim is to show how triangular shape is stronger than a square. Two and two, holding hands on each other shoulders and then one person is pushing from the side. And then to feel the difference you ad one person so that three persons holds their hands on each others shoulders', standing in a triangular shape. Then another person pushes again. I find it important and a great opportunity to ground knowledge in your own body. You will never forget what is in you body memory.

Social justice is the focus of this magazine. My point here is that as being a national authority, a national museum, we have to do our best to try to even out the differences in society by focusing on providing the best learning situation possible, in that way we can work to reduce the gap. Architecture is such a vital part of our being, it is nothing that we can get a way from. Therefore, it is very important to get children (and adults) to know why their surroundings look and function they way they do. In that way we get better decision makers in the future.

\section{Work with your hands!}

After the tour in the exhibition we enter our studio or workshop area and let the students work in smaller groups, preferably groups of four people. Our experience says that that is the ultimate size for this workshop. Three is a bit too few and five, to many hands on the work. The workshop is divided into two parts: construction and presentation. The task to build is connected to the theme that the teachers have chosen. We also use this workshop to explain the different professions that creates our built environment. If the teacher has chosen to work with the city-planning track, we let the participants become city planners. We provide a baseplate with the measurement of $200 \times 200 \mathrm{~mm}$. Onto that, they glue paper in different colors that represent hi-density area (grey), water (blue), green space or low-density area (green), main roads (black) and secondary roads (beige). We then provide them with blocks of MDF with the measurement $14 \times 14 \mathrm{~mm}$ that symbolize buildings. Each teams have to solve communications, transports, functions and organization of the city with a sustainable approach for the future. They also have to collaborate, make choices and compromise, just as in real life.

Towards schools we always work with workshops as we find it important to work with your hands as well as your head. I often find that participants that have been quite unfocused during the tour in the exhibition have noticed more than you could guess and in the workshop they often excel. Some people don't have easy to express themselves through speech or writing, two skills that in school are highly valued. But there is also a value in being able to express yourself by doing. Sometimes I hear people say that they can't draw or paint but I have never heard anyone in my workshops saying, I can't build. That is something that working to our advantage.

\section{Choices}

In most of our workshops we aim to work in simple materials, materials that schools easily can have access to. Color paper, overhead film and tape. The two luxury things that we use are glue guns, more and more common in Sweden and Artstaws, thin paper 
tubes. We strive to work in simple materials for several reasons. One is that schools have little money to buy special material that would only be used for one workshop. We want the schools to be inspired by the workshop and for the teachers to gain more selfconfidence to work with three-dimensional work. Tape, color paper and over-head film are some things that exist in every school in Sweden.

Reason number two is that we also struggle with the conception of that architecture is something that just architects does, that it is something difficult. We want to show that we all contribute to architecture and that we all have a good deal of knowledge but not always the words to describe it. Therefore, we try to lower the threshold by using materials that the participants and teachers are used to deal with.

At the end of the program the participants present their work to each other. To engage the participants, I sometimes ask one group to present and another to give positive feedback on the suggestion. This is something that I use in particular when we have the program about architecture history. Then the groups with younger pupils are building a house model with inspiration from an animal. They are asked to think of an animal and what characteristics it has and then implement that in the building. The older pupils or participants they get a type of building that they should give us the best solution to. It can be a house of culture, sport arena or a museum.

Here we try to show them how architects sometimes work with the process of parallel assignments. Simply explained it is an alternative to architectural competitions. With parallel assignments several architecture offices work on the same building and the client can then choose the best ideas from each proposal and join them in the final building. If it is a competition the client follows the suggestion of the winner. It is therefore I ask the responding group to pick up one idea that they specifically liked from the suggestion presented. In the end we have a collection of good ideas and they can all close their eyes while I try do describe how the final building would look like. In the best of worlds, the school take back those ideas and build it. We always give the group an opportunity to bring back the models that they have built.

\section{The importance of teachers}

There is a limit to how many school groups we can meet at ArkDes, therefore teachers are a very important group for us. In that way we reach many children, more that we can directly meet in our eye to eye. We work with open teacher's evenings that is for free to inspire teachers on how to work with architecture and design, both in our museum but also in their classrooms. ArkDes provides workshops for the collegium that they can book for a fee, but most important we work though collaborating with the teacher training at Stockholm University. Here we meet both the teachers and the teachers to be.

In Sweden for the moment you educate yourself to become a pre-school teacher, teacher for the early years (children age 6-12), the later years (children age 13-15) or for the upper-secondary (gymnasium) and then the students are 16-18 years old. When we work with the teacher training it is with teachers to be with alignment towards the early years. We meet them within their courses of technology didactics. The last group from Stockholm University's teacher training is teachers that are graduates and have worked for a while but want to complement their degree with more technology studies. 


\section{International projects}

We also work outside ArkDes buildings with different collaborations to strengthen our possibilities to reach out. We have been working with children living in orphanages in Moldova, Ukraine and Belarus. The theme was "HOME" and the question was "What is home?" This is one of these projects that different professionals work together with different goals, but are still united in the respect for the children. From ArkDes point of view this was a project to provide marginalized children with an opportunity to make their voices heard in a public place. What the outcome was much more, but I will comment on that later on.

In this project and the following we worked with a dance company, Lava Dansproduktion and the choreographer Benno Voorham. It became a close collaboration between architecture education and contemporary dance with influences from contact improvisation. Together we put together a series of architecture workshops in combination with movement. I will take you through a couple of the exercises. As we repeated the project in three different counties there were a development and a constant adjusting to the different situations. Also within one country you could have one plan for the day and then having to change the exercise, stop it or giving it much more time than planned.

\section{Working in another culture}

A high level of responsiveness was demanded in these projects for many reasons. I was not working with my mother tongue and my knowledge of Russian, Belarusian, Moldovan and Ukrainian is very limited. But yet, the spoken language is just one language; we have so many more to communicate though. Of course I had someone that could translate for me as well but I was a little bit surprised how easy it was to read what was going on in the room during the workshop, immediately to see when some group got stuck or got a problem with the assignment.

We started with an exercise of making nametags. I asked the children to think of a piece of furniture (or a utensil) that could represent them. Then in simple materials they built sofas, beaters, cupboards, pots, mirrors etc. An exercise as a start of getting to know each other and start talking of why did you chose this or that. I may look simple but we tell a lot about ourselves in this way, maybe just a fraction but yet, something. I also find that people think it easier to talk "through" something else, than talking about them selves straight on. And the stories told, they were life changing. It is also a way to work together, side by side with the same exercise. Not supervising but working together. So a question to you dear reader: What utensil would you be today? And why?

It was an excellent combination to do workshops before lunch and then after lunch we danced/moved together and communicated through our bodies, it was truly liberating. We tried to work on the same theme in the workshop and in the dance sessions. When we were building boxes of feelings we also danced in boxes taped onto the dance floor.

The second workshop was a quick one; we did speech bubbles, big ones. It happens something when we work in a big scale. A lot of children are used of working on A4's but not in larger formats. I posed a question to the group: What is the first word that pops up in your mind when you hear the word...home? Take that word and write it down in your speech bubble. We then did them by cutting the bubble out of paperboard and used big markers to write our word. Sometimes we played with the words by 
building a story by using the different words with a narrator in the middle of a circle making up the tale. A version of that is to throw in your word in the tale so that the narrator has to integrate your word in the story. It also became a language lesson, as we needed the words in both their native thong as well as in English so that Benno and I could understand what it stood on the speech bubbles.

Early dance exercises that we did aimed to support their bodily self-confidence by trying to find equilibrium between you and a friend, standing toe to toe, holding hands and then slowly lean back till you create a triangular shape. Then you slowly can start to move but always keep equilibrium. You can also do the opposite and lean together, shoulder to shoulder or head to head and under constant contact move through the space.

After that it differed in what order we did the workshops so the order here described is not strict. The project Home was divided into several parts starting with a pilot where about 20-30 children were involved. Then the project started a couple of months later and then it was between 15 and 20 children taking part. In the final stage when the performance was made and performed there were six or seven children acting on stage. Sometimes the children taking part of the project varied a little bit from the pilot to the final project so some of the workshops was repeated or deepened.

\section{Workshop examples}

Personal maps. Maps can look very different from each other but what they have in common are that they describe a reality in scale. In this exercise we draw our own personal maps of places that are important for us. In the pilot we asked the children to draw places that are important for them today and in the project we deepened the exercise by letting them draw one map of important places for them when they were six and one for the future along with places of importance today. It is good to do this exercise on a paper that is minimum A3 and using a marker or a pen rather than a pencil. Crayons can work if they leave a clear imprint, otherwise it can bee a bit lame.

I find it important to work in as many different materials as possible. Each material gives us a specific possibility to express one thing while another material gives us another possibility. There is also a thought in that that some people like to draw, some to build and some to tell a story. With a variety everyone finds something that they like and find it easy to communicate through.

If you were to leave home and move to a new place, which three items would you bring to make you feel at home at the new place? A very relevant issue in todays society for a lot of people and for these children a reality. With very few personal items each becomes very important. I asked the children to make the items in plastilina (colored modelling clay) and then draw a room where the items fitted. There were district differences between the different counties telling much about the situation the children were living in. One country the beds were most common, in one the cellular phone and in one the bible.

Mixed together with the workshops there were dance sessions. Quite early we practiced the feeling of being in a group and respond to each other by doing different exercises. There were the exercise Start and Stop, that one is the leader and when that person stops, the group stops and when the leader starts everyone starts to move. An alternative version or a development on that is that the group moves and when one 
person stops, the group stops. This is to practice our attention to what happens in the space and act on the impulses that we get from our surroundings. The stop and start exercise can be developed into that you also ad different speeds as walking slow, fast, running etc. In another session we did the diamond, one person leads the group and is standing/moving with the rest of the group behind. When the leader turns some one else becomes the person that stands in the front and in this way you take turns to be the leader.

One of my favorites is the Box of Feeling. It can be altered into different questions but the idea is always the same. You are supposed to build a feeling inside a box so clear that when another person is looking into your box, the person will feel the feeling that you intend. In this case we asked the children to think what feeling they get when they hear the word home. And I was very clear that it was the relation between the word home rather and then configure that into a cardboard box using colored paper, artstraws, scissors, glue, yarn, and fabric as well as cut outs from magazines. They can also control the light situation inside the box by doing different kinds of openings in the box. If you want to play with light one can always glue thin tissue (silk) paper in different colors over the openings. The difficulty in this exercise is that you are NOT supposed to make a room with chairs, a celling, windows etc. It is the feeling that you are going to form. When you are done one can take a strong flashlight and move it above the box to see how the light and scenery changes while the flashlight change its angle. It becomes a little bit like how the sun travels over the sky during the day. This also became a popular exercise that we sometimes made the decision to spend a lot on time on.

One of the more spectacular and imaginative workshops is the Superhero family. An idea that originally comes from Iceland and that I saw an Icelandic architect by name Guja Dögg facilitate in Lahti, Finland during Finland's year of being the European Capital of Culture. The concept is that you as the workshop facilitator create families (four or five in each family). Then everyone has to choose a super power that they would like to have, for example being invisible, have extendable arms etc. The task is then to create a home for all these different needs using tape, strings and sticks. Of cause the children get so into this exercise that they find a lot of other materials. When the building is built they transform themselves into super heroes by using black plastic bags, black face paint and black tape. A little show is then taking place when each family present their building and how it is adapted to their specific need. Striking is how much care they take of each other and how they really adapt the space to the needs. Wonderful stories are built.

Sometimes it is best to precede the Superheroes workshop with a workshop that more focuses on different ways to construct a space. This is an exercise that can serve different purposes, it can focus on construction or you can let it have a subtler meaning. The workshop starts by that I let the children do a space analysis of a place by using a simple map of the space. They are then looking and experiencing the space and notice things like light, wind, entrances, movement, one thing on a separate map. When you look on the maps that are created you can do a space analysis to decide where the best place for example a bench is. Here I asked them to identify the place were they felt as safe as possible. When all this was done they were to erect a construction on that place.

As they have been working in four different groups I presented four different materials that they were going to use. One group got wooden or bamboo sticks, one fabric, one strings and the last one rolled paper rolls. In addition to their material I gave them 
some yarn and tape, preferably masking tape (do not use duct tape because it is to strong and gives you a huge job dismantling the constructions). Then they explore the different possibilities that each material holds and finds pros and cons designing with them. And as always the children present their ideas to each other in the end.

On occasion they are out of energy and standing to listen to a lot of presentations is almost impossible. If you have a choice, divide them into smaller presentation groups so that they can present and listen just once, or can they do the presentation by filming it and then show the film later on or just take the presentation another day. As I have stated before, I find it important to pay attention to how the group reacts and act on the input that you get so that the learning situation becomes as good as possible.

The last exercise that I will describe here is a drawing exercise. Here it is important to use a big paper, at least A2 in size. Start by folding two sides towards each other so that they meet in the middle of the paper. You have now created an outside and an inside. On the outside you draw or paint where you live now and on the inside you draw where you live in the future. It becomes a very beautiful and symbolic effect to have now on the outside and the future a bit hidden inside. And again, I find it useful to work with big sheets of paper. You get another relationship between the paper and your body when you have to interact much more physically whilst drawing.

\section{Magic results}

When working in projects I often experience The Day Three Crisis. The first day, everything goes well and you start to get to know each other, day two you are still polite and day three the participants feel secure enough to start to criticise and questioning. Day four you are back on track. In a project there are things that is ok, something that definitely doesn't work the way you thought and then there are those magic moments.

In project Home there were a girl in the Superheroes family workshop that always will be etched in my memory (or actually there are two but here comes one). The girl had the super power to become invisible by just turning her hat. The rest of the family had powers as turning everything into fire or to prophesy. The child that could start a fire had a small boxed room so that her fire wouldn't spread and the seers had a space where she could "turn off" her ability to be able to rest. It was a very nice little house under a tree and very well planned. We all looked forward to hear the invisible superhero to present her place but all we saw was a swab ladder going up the tree. She presented her ability and then explained that as she could be invisible, so was her space. It was so beautiful with the swab ladder going up into the crown. It really ticked everyone's imagination.

All the stories told, workshops made and dance sessions together built the foundation to a dance performance. On stage there were six professional dancers that all had been taking part of the project and then six or seven children. The performance toured each country and then the whole project was repeated in the next country. On stage a sound artist were present as well so it was a meeting between architecture, dance and music. The audience responded very well to the performance saying that it was highlighting important questions, that they were very moved and that the children were fantastic. In 
total about 10000 persons have seen the performances and then also heard the children's stories. Children that society don't very often listen to or give space to.

In another project, this time in Sweden, working with teenage refugees, the magic moment came when we were doing a movement exercise called the mirror. In the group there were a big group of Afghani boys and then a mixed group from a lot of different counties. They had recently arrived to Sweden and didn't know each other that well, so different situation than in project Home where the children knew each other. We had been forewarned that there were big troubles in the group and little respect between different gender and nationalities. One of the girls had a vision loss and was very reclusive, always seeking support from an adult at all times until we started the Mirror exercise. You divide the group into two and from each group a leader stands in front of the half group. The leaders of the two groups are then starting to act in silence as if they were each other's mirror images. And behind them the groups follows the in their turn.

We were all a bit surprised when the very cautious girl position herself in the front position and everyone else followed her. You could feel the concentration in the air and everyone was there in both body and soul. The teachers sat on the side actually crying because they were so moved by what happened and for maybe ten minutes there were full focus on the exercise and when the music stopped everyone burst out into hurrays' and applauses.

Afterwards the teachers told us again that they had such issues with respect in the group and that they were working a lot with value work but in this exercise we had succeed to do all that work for them. Now they had a totally and much better starting point for their work in the classroom. I also believe that we gave them strength to continue and prof for that it was possible to succeed.

These projects have not been evaluated or the results haven't been measured in any formal way. What I and we have been our own experiences and what the adults and children involved has told us. A filmmaker followed Project Home and the documentary of the project called DOM-HOME has won the Golden Cube Awards, an award that the UIA (Union Internationale des Architectes) has to promote architecture education. You can find the documentary via ArkDes webpage, www.arkdes.se. It is 23 minutes well spent if you ask me. In this documentary one of the girl's state that before she didn't trust adults but now she has learnt that you can do that. I also remember that in one of the gatherings in Belarus, the participants made a reflexion that they now saw each other with new eyes and that they had an opportunity to show other sides of themselves.

It is exhausting and very intensive while you are in the process as all your tentacles are out and try to understand what's happening and block for this or that, redirecting and support the process. And it is worth every penny and is extremely rewarding when you succeed, when you make a difference.

\section{Discussion and conclusions}

I find that this way of working with architecture education is a very rewarding way to work as an educator and also that it provides the participants with different kind of skills and more opportunities to express themselves. We are often very focused on oral or writing skills but here we support the children that are better to express themselves in other ways. And I must stress that that is equally important as writing or talking. If 
you look at the Swedish school curricula today it focusses on four different abilities: Understanding, Facts, Skills and Familiarity. We also talk a lot about a wider idea of what literacy is.

Architecture education is fantastic to fill and work with those abilities because architecture education gives us a holistic way of learning and working. And as we all have a relationship to architecture it is easy to start talking about and working with. Within architecture education you can fulfil goals in language, mathematics, technology, history, art and more. But you also get a better understanding for your surroundings and that gives you a great starting point for further discussions and taking part of the development of society.

I can see that the children taking part in architecture education (maybe especially the ones with low self-esteem) gets higher self-esteem and build up a lot of self-confidence. Those are important feelings if you are going out into the society and want to take an active part in the development of it. That in combination with a higher understanding and knowledge of architecture and city building is a fantastic combination. We need knowledge to be able to change the future.

\section{References}

Bamford, A. (2009). The wow factor. Global research compendium on the impact of the arts in education. Münster: Waxmann Verlag.

\section{Brief CV of the author}

\section{Madeléne Beckman}

Curator Learning at the department Exhibitions and Learning at The Swedish Centre for Architecture (ArkDes) and had a career as an educator, curator and teacher at different museums. Madeléne's work at ArkDes has focussed on working with young people and teacher training since she begun there 2002. Creating educational programmes, making participatory exhibitions as well as giving lectures and facilitating workshops in Sweden and abroad have been a part of her career. She is also a funding member and a board member of Playce, an international network for built environment education and is a co-opted member to ARKiS (Architecture in Schools) in Sweden. Madeléne Beckman has studied Integrated Conservation of the Built Environment at Gothenburg University and has published articles in magazines, books and blogs on architecture history, gender and architecture education. Email: madelene.beckman@arkdes.se 